\title{
Heating and Biochemical processing of Kariya (Hildegardia bateri) seeds: Chemical composition, antinutrients and functional properties
}

\author{
Saka Olasunkanmi Gbadamosi, Olamide Esther Aluko and Abiodun Victor Ikujenlola* \\ Department of Food Science and Technology, Obafemi Awolowo University, Ile-Ife, Nigeria
}

\begin{abstract}
This study evaluated the effects of processing methods on chemical composition, physicochemical and functional characteristics of defatted and full fat flour samples from processed kariya seeds. The seeds were cleaned and subjected to heating processes (cooking and autoclaving) and biochemical processes (germination and fermentation), the seeds were dried and milled to flour. A portion was defatted and another portion left as full fat. The flour samples were analysed for the selected parameters using standard methods. The results showed that the bulk density ranged between $0.52-0.75 \mathrm{~g} / \mathrm{ml}$. The oil absorption and water absorption capacities ranged from $65.50-144.60 \%$ and $46.40-218.50 \%$ respectively. The water absorption and swelling capacities of the defatted samples increased with temperature increase. All processing treatments were found to increase protein content (22.16-49.94\%) and in vitro digestibility (27.86-82.63\%). Both the heating and biochemical processes reduced the level of antinutrients significantly. In conclusion, the kariya flour samples subjected to both fermentation and germination had better chemical composition, physico-chemical and functional properties.
\end{abstract}

\section{Introduction}

Kariya (Hildegardia bateri) is a rainforest tree of about $30 \mathrm{~m}$ in height. It belongs to the mallow family-Malvaceae and to the subfamily Sterculiaceae [1]. In West Africa, kariya is used as ornamental tree because of its bright beautiful flowers which blossom during the dry season. The flowers, which are usually borne on leafless branches, mature into one-seeded pods, each about $5 \mathrm{~mm}$ in length, bearing a peanut-like seed in a nutshell. The mature pods drop completely when dry and are disposed as refuse in many places. The kernels are eaten raw or roasted like groundnuts in some part of West Africa countries [2], it is also processed and used as condiments in traditional food preparations. The proximate composition (17.5, 37.5, 6.5, 2.5\% of crude protein, fat, crude fibre and ash respectively) and fatty acid profile of these biomaterials provide the basis for their use as food or oil [3]. It contain some antinutrients according to the report of Ikujenlola $e t$ al. [4], some of which might be responsible for the death of experimental animals during feeding trials.

Previous works on kariya showed that it is rich in protein (17.5\%) and fat $(37.5 \%)$. High quality protein products such as protein concentrate, isolate and hydrolysate with good functional properties and high in vitro protein digestibility could be obtained from kariya seed flour [3,5-7]. One of the methods employed to increase the protein content and improve the functional properties of oil seed is to reduce/ remove the fat thereby extending the shelf life of the flour. This can also increase the functionality and hence application of the flour in food formulations. However, the utilisation of any food protein flour as foods or food ingredients will largely depend on its physicochemical and functional characteristics as well as the safety of such product.

Food processes such as germination, fermentation, autoclaving, boiling, roasting, etc. have been reported to have positive effect on the quality parameters (sensory, functionality, safety, etc.) of food products [8].
This study was designed to investigate the effect of various processing methods on physico-chemical and functional properties of kariya kernel flour with a view to providing useful information for its possible application in food system.

\section{Materials and Methods}

\section{Materials}

Kariya pods were gathered from kariya trees in Obafemi Awolowo University, Ile-Ife, Nigeria. The reagents used were of analytical grade and were purchased from Sigma Aldrich chemical company, USA.

\section{Methods}

\section{Processing of kariya whole and defatted flour samples}

The matured pods were ruptured to remove the seeds and the seeds were manually dehulled and winnowed. The seeds were divided into seven portions, one portion served as the control (i.e. unprocessed/raw seed) and each of the remaining six portions was subjected to different processing treatments: cooking/boiling (at $100^{\circ} \mathrm{C}, 1 \mathrm{~h}$ ), autoclaving (at $121^{\circ} \mathrm{C}, 15 \mathrm{psi}, 30 \mathrm{~min}$ ), roasting (at $100^{\circ} \mathrm{C}, 1 \mathrm{~h}$ ), germination (at $28 \pm 2^{\circ} \mathrm{C}, 96 \mathrm{~h}$ ), fermentation (at $28 \pm 2{ }^{\circ} \mathrm{C}, 96 \mathrm{~h}$ ) and combination of germination (at $28 \pm 2^{\circ} \mathrm{C}, 96 \mathrm{~h}$ ) and fermentation (at $28 \pm 2^{\circ} \mathrm{C}, 96 \mathrm{~h}$ )

*Correspondence to: Ikujenlola AV, Department of Food Science and Technology, Obafemi Awolowo University, Ile-Ife, Nigeria, E-mail: avjenlola@gmail.com

Key words: fermentation, germination, in-vitro protein digestibility, defatted flour, temperature, phytate

Received: August 21, 2020; Accepted: September 25, 2020; Published: September 28,2020 
$[7,8]$. The processed seeds were dried at $60^{\circ} \mathrm{C}$ for $12 \mathrm{~h}$ in the cabinet drier, milled and sieved into fine flour through $200 \mu \mathrm{m}$ mesh sieve. Flour sample from each processing method was divided into two portions. The first portion was left as full fat flour sample and the second portion was defatted using cold acetone by stirring over magnetic stirrer for $4 \mathrm{~h}$ $(1: 4 \mathrm{w} / \mathrm{v}$; flour: acetone $)$ at room temperature.

\section{Proximate Composition of processed kariya seed flour samples}

The proximate composition (moisture, protein, crude fibre, fat, ash and carbohydrate) of processed kariya seed flour was determined using standard method of AOAC [9]. The energy value was calculated using Atwater factor according to Alobo et al. [10].

\section{Moisture}

Moisture content of the samples was determined by the standard AOAC [9] official method. The results were expressed as percentage of dry matter shown in Equation 1;

Moisture content $(\%)=\left(\mathrm{W} \_1-\mathrm{W} \_2\right) / \mathrm{W} \_1 \times 100(\%)$

W_1=weight of flour before drying

W_2=weight of flour after drying

\section{Protein}

The protein content of the samples was determined using the AOAC [9] method. The nitrogen content was obtained as shown in Equation 2 and multiplied by 6.25 to obtain crude protein content.

Nitrogen content,NC $=(1.401 \times 0.2 \times(\mathrm{A} 1-\mathrm{B} 1)) /($ Sample weight $) \quad 2$

$\mathrm{A} 1=$ titre value of sample

$\mathrm{B} 1=$ titre value of blank

Protein content $=6.25 \times \mathrm{NC}$

\section{Crude fat}

Crude fat was determined by the AOAC [9] method using Soxhlet apparatus (Sunbim, India). The quantity of oil obtained was expressed as percentage of the original sample used as shown in Equation 3;

$$
\begin{aligned}
& \text { W_4 =weight of flask+oil } \\
& \text { W_5=weight of empty flask } \\
& \text { W_6=weight of sample }
\end{aligned}
$$$$
\text { Crude fat }(\%)=\left(\mathrm{W} \_4-\mathrm{W} \_5\right) / \mathrm{W} \_6 \times 100(\%)
$$

\section{Ash}

Ash content of the samples was determined by the AOAC [9] method using muffle furnace (Carbolite AAF1100, United Kingdom). Ash content was expressed as percentage of the weight of the original sample as shown in Equation 4;

$$
\begin{aligned}
& \text { Ash content }(\%)=\left(\left(\mathrm{W} \_7-\mathrm{W} \_8\right) / \mathrm{W} \_9\right) \times 100(\%) \\
& \text { W_7=weight of crucible+ash } \\
& \text { W_8=weight of empty crucible } \\
& \text { W_9=weight of sample }
\end{aligned}
$$

\section{Crude fibre}

Crude fibre was determined as described by AOAC [9] using $2 \mathrm{~g}$ $\left(\mathrm{W}_{12}\right)$ of the samples. The crude fibre was obtained using the equation below (Equation 5);

$$
\begin{aligned}
& \text { Crude fibre }(\%)=\left(\left(\mathrm{W} \_10-\mathrm{W} \_11\right) / \mathrm{W} \_12\right) \times 100(\%) \\
& \text { W_10=weight of crucible after ashing } \\
& \text { W_11=weight of crucible after oven drying } \\
& \text { W_12=weight of sample }
\end{aligned}
$$

\section{Carbohydrate}

Carbohydrate was expressed as a percentage of the difference between the addition of other proximate composition and 100 as shown in Equation 6;

Carbohydrate $(\%)=100-($ moisture content + crude fat + crude fibre+ash content+crude protein)

\section{In vitro protein digestibility determination}

In vitro protein digestibility of samples was measured according to the method described by Chavan et al. [11]. Protein digestibility was obtained by using the equation shown below;

$$
\text { In vitro protein digestibility }(\%)=\left(\frac{I-F}{I}\right) \times 100
$$

where: I- protein content of sample before digestion

protein content of sample after digestion

\section{Determination of antinutrient content}

The concentrations of some selected antinutrients (tannin, oxalate, saponin and phytate) were determined.

\section{Determination of Tannin}

The modified vanillin-hydrochloric acid (MV-HCl) method of Price et al. [12] was used. The following calculation was adopted: Tannin $=(\mathrm{Xmg} / \mathrm{ml} \times 10 \mathrm{ml}) /(0.2 \mathrm{~g})=50 \times \mathrm{mg} / \mathrm{g}$

where $\mathrm{X}$-value obtained from standard catechin graph

\section{Determination of oxalate}

Oxalate was determined by the method of Falade et al. [13]. The oxalate was calculated as the sodium oxalate equivalent as shown in equation below.

$1 \mathrm{ml}$ of $0.05 \mathrm{M} \mathrm{KMnO}_{4=} 2 \mathrm{mg}$ sodium oxalate equivalent/ $\mathrm{g}$ of sample.

\section{Determination of saponin}

The spectrophotometric method of Brunner [14] was used for saponin analysis.

Saponin $=($ Absorbance of sample $\times$ dil.factor $\times$ Gradient of standard graph curve $) /($ Sample weight $\times 10,000).(\mathrm{mg} / \mathrm{g})$

\section{Determination of phytate}

The phytate content of the samples was determined adopting the method described by Reddy et al. [15]. The concentration of the $\mathrm{FeCl}_{3}$ is $1.04 \% \mathrm{w} / \mathrm{v}$ and Mole ratio of Fe to phylate $=1: 1100 \mathrm{x}$ weight of sample 
Concentration of phytate phosphorous=Titre value $\mathrm{x} 0.064$.

\section{Physicochemical and functional properties determination of kariya seed flour}

Bulk density was determined by the method of Okezie and Bello [16]. The $\mathrm{pH}$ was measured by making a $10 \% \mathrm{w} / \mathrm{v}$ suspension of the sample in distilled water and the $\mathrm{pH}$ of the suspension was measured with a $\mathrm{pH}$ meter (Model HI 9812F, Hanna instrument, Woonsocket RI USA). Water absorption capacity (WAC) was determined at room temperature and at temperatures ranging from 60 to $90^{\circ} \mathrm{C}$ using the method of AACC [17]. Oil absorption capacity (OAC) of the samples was determined by the centrifugation method described by Beuchat [18]. Swelling capacity (SC) was determined using the method described by Takashi and Sieb [19]. Emulsifying activity index (EAI) and emulsifying stability (ES) at natural $\mathrm{pH}$ was determined by the method described by Gbadamosi et al. [20].

\section{Statistical analysis}

All determinations were carried out in triplicates and results were subjected to analysis of variance (ANOVA) and means separated by Duncan Multiple Range Test.

\section{Results and discussion}

\section{Proximate composition of full fat and defatted flour samples of processed kariya seeds}

The proximate composition of processed kariya flour samples is shown in Table 1. The moisture contents of the flour samples produced from various processing methods varied significantly $(\mathrm{p}<0.05)$ between 3.50 and $20.33 \%$ with roasted sample $(\mathrm{R})$ having the lowest and defatted flour of germinated-fermented sample (DGF) having the highest. Low moisture content increases shelf stability [21] while high moisture content encourage proliferation of spoilage microorganism in food systems.

The fat content of the samples ranged between 6.10 and $50.98 \%$. There was significant increase $(\mathrm{p}<0.05)$ in fat content of fermented and germinated-fermented samples however, significant decrease was observed in germinated sample. Li et al. [22] reported a significant decrease of fat content when groundnut seeds were germinated. This could be due to the increased activities of lipolytic enzymes during germination which hydrolyses fat components into fatty acid and glycerol [23].

The crude fibre content ranged from 0.15 to $2.10 \%$. The crude fibre content of defatted flour samples was lower than those of full fat flour samples. Similar observation was also reported by OCheme et al. [24] for defatted groundnut.

Protein contents varied from $22.16-49.94 \%$ with raw sample having the lowest value while defatted fermented sample had the highest value. All the processing conditions increased protein content significantly. Fawale et al. [25] reported increase in protein content of cooked and fermented kariya seeds. The protein contents of defatted flour samples were significantly higher $(p<0.05)$ than the protein contents of full fat flour samples. Higher protein content observed in fermented sample is similar to the observations by Sathya and Siddhuraju [26] on fermented Pakia roxburghii (yongohak) seeds and Fawale et al. [25] on fermented kariya seed. This could be attributed to structural proteins that are integral parts of the microbial cells [27]. Germination process also increased protein content and this could be attributed to the net synthesis of enzymes by germinating seeds which might have resulted in the production of some amino acid during protein synthesis[28].

It was observed that carbohydrate reduced in all the full fat samples. However, defatting process caused significant increase in the carbohydrate content of the treated flour. Similar observation was reported by Fawale et al. [25] and Kang et al. [29].

There was significant difference $(\mathrm{p}<0.05)$ in the ash content of the samples. The values ranged from $2.88-7.65 \%$ with defatted roasted sample having the highest value while boiled sample had the lowest value. The range of ash content values are within the range of values (2.11-7.98\%) reported by Udoh [30] for full fat and defatted flour of fluted pumpkin seed. Defatting process resulted in increase in ash content, this was similar to observations reported by Ogunsina et al. [31] and Adebayo et al. [5] for kariya kernel flour. Ash content is an indication of the total mineral content in food.

The energy value varied from 330.15-613.40 kcal with defatted germinated-fermented sample having the lowest value while full fat germinated-fermented sample had the highest energy value. There was significant decrease $(\mathrm{p}<0.05)$ in the energy value of boiled, germinated and all defatted flour samples but there was significant increase $(\mathrm{p}<0.05)$ in the energy value of fermented and germinated-fermented sample.

Table 1. Proximate composition and in vitro protein digestibility of raw and processed Kariya seed flour (\%)

\begin{tabular}{|c|c|c|c|c|c|c|c|c|}
\hline Sample code & Fat & Crude fibre & Protein & Moisture & Ash & Carbohydrate & $\begin{array}{c}\text { Energy value } \\
\text { (kcal) }\end{array}$ & $\begin{array}{l}\text { In vitro protein } \\
\text { digestibility }\end{array}$ \\
\hline $\mathrm{Ra}$ & $32.05 \pm 0.15^{\mathrm{d}}$ & $0.58 \pm 0.03^{\mathrm{de}}$ & $22.16 \pm 0.16^{j}$ & $5.95 \pm 0.10^{\mathrm{i}}$ & $4.43 \pm 0.23^{\mathrm{e}}$ & $37.85 \pm 0.22^{\mathrm{c}}$ & $28.44 \pm 0.15^{\mathrm{d}}$ & $27.86 \pm 0.65^{\mathrm{m}}$ \\
\hline B & $31.35 \pm 0.20^{\mathrm{e}}$ & $0.18 \pm 0.25^{\mathrm{g}}$ & $27.00 \pm 0.20^{\mathrm{h}}$ & $4.23 \pm 0.53^{\mathrm{fg}}$ & $2.88 \pm 0.18^{\mathrm{g}}$ & $28.72 \pm 0.55^{\mathrm{g}}$ & $05.88 \pm 1.25^{\mathrm{e}}$ & $33.33 \pm 0.27^{\mathrm{k}}$ \\
\hline $\mathrm{R}$ & $37.00 \pm 0.05^{\mathrm{c}}$ & $0.30 \pm 0.05^{\mathrm{fg}}$ & $24.90 \pm 0.50^{\mathrm{i}}$ & $3.50 \pm 0.10^{\mathrm{hi}}$ & $5.30 \pm 0.30^{\mathrm{d}}$ & $34.61 \pm 0.82^{\mathrm{e}}$ & $571.04 \pm 1.82^{\mathrm{c}}$ & $31.58 \pm 0.49^{1}$ \\
\hline A & $32.53 \pm 0.33^{\mathrm{d}}$ & $0.68 \pm 0.08^{\mathrm{d}}$ & $27.56 \pm 0.46^{\mathrm{h}}$ & $3.85 \pm 0.30^{\mathrm{gh}}$ & $4.98 \pm 0.33^{\mathrm{d}}$ & $30.43 \pm 0.42^{\mathrm{f}}$ & $524.73 \pm 2.14^{\mathrm{d}}$ & $34.68 \pm 0.52^{j}$ \\
\hline $\mathrm{G}$ & $28.40 \pm 0.55^{\mathrm{f}}$ & $0.25 \pm 0.05^{\mathrm{fg}}$ & $31.50 \pm 0.50^{\mathrm{f}}$ & $4.78 \pm 0.13^{\mathrm{ef}}$ & $4.48 \pm 0.08^{\mathrm{e}}$ & $30.60 \pm 0.48^{\mathrm{f}}$ & $504.00 \pm 3.15^{\mathrm{e}}$ & $37.49 \pm 0.44^{\mathrm{i}}$ \\
\hline F & $49.28 \pm 0.08^{\mathrm{b}}$ & $1.80 \pm 0.01^{\mathrm{b}}$ & $34.13 \pm 0.10^{\mathrm{d}}$ & $5.35 \pm 0.10^{\mathrm{e}}$ & $3.50 \pm 0.20^{\mathrm{f}}$ & $5.94 \pm 0.43^{\mathrm{i}}$ & $603.78 \pm 0.82^{\mathrm{b}}$ & $46.15 \pm 0.45^{\mathrm{g}}$ \\
\hline GF & $50.98 \pm 1.18^{\mathrm{a}}$ & $2.10 \pm 0.25^{\mathrm{a}}$ & $33.63 \pm 0.43^{\mathrm{d}}$ & $5.38 \pm 0.18^{\mathrm{e}}$ & $3.23 \pm 0.03^{\mathrm{fg}}$ & $4.69 \pm 0.67^{\mathrm{j}}$ & $613.40 \pm 7.82^{\mathrm{a}}$ & $45.35 \pm 0.35^{\mathrm{h}}$ \\
\hline DB & $9.13 \pm 0.03^{\mathrm{i}}$ & $0.18 \pm 0.01^{\mathrm{g}}$ & $32.81 \pm 0.60^{\mathrm{e}}$ & $7.13 \pm 0.13^{\text {cd }}$ & $4.20 \pm 0.10^{\mathrm{c}}$ & $46.59 \pm 0.72^{b}$ & $399.77 \pm 6.06^{\mathrm{f}}$ & $75.04 \pm 0.44^{e}$ \\
\hline DR & $9.18 \pm 0.38^{\mathrm{i}}$ & $0.20 \pm 0.00^{\mathrm{g}}$ & $33.88 \pm 0.44^{\mathrm{g}}$ & $4.90 \pm 0.25^{\mathrm{e}}$ & $7.65 \pm 0.15^{\mathrm{a}}$ & $49.19 \pm 0.39^{\mathrm{a}}$ & $414.90 \pm 2.27^{\mathrm{f}}$ & $72.61 \pm 0.31^{\mathrm{f}}$ \\
\hline DA & $6.10 \pm 0.02^{j}$ & $0.45 \pm 0.05^{\text {ef }}$ & $33.50 \pm 0.40^{\mathrm{d}}$ & $6.85 \pm 0.05^{\mathrm{d}}$ & $6.45 \pm 0.15^{\mathrm{b}}$ & $46.65 \pm 0.38^{b}$ & $375.50 \pm 0.20^{\mathrm{h}}$ & $76.34 \pm 0.48^{\mathrm{d}}$ \\
\hline DG & $10.33 \pm 0.18^{\mathrm{h}}$ & $0.15 \pm 0.05^{\mathrm{g}}$ & $38.77 \pm 0.35^{\mathrm{c}}$ & $7.65 \pm 0.65^{\mathrm{c}}$ & $6.40 \pm 0.30^{\mathrm{b}}$ & $36.70 \pm 0.43^{\mathrm{d}}$ & $94.85 \pm 2.55^{\mathrm{g}}$ & $79.70 \pm 0.40^{c}$ \\
\hline $\mathrm{DF}$ & $12.63 \pm 0.23^{\mathrm{g}}$ & $1.25 \pm 0.25^{\mathrm{c}}$ & $49.94 \pm 0.24^{\mathrm{a}}$ & $12.38 \pm 0.68^{\mathrm{b}}$ & $5.83 \pm 0.23^{\mathrm{c}}$ & $22.10 \pm 1.29^{\mathrm{h}}$ & $401.83 \pm 2.57^{\mathrm{f}}$ & $82.63 \pm 0.47^{\mathrm{a}}$ \\
\hline DGF & $8.83 \pm 0.75^{\mathrm{i}}$ & $1.88 \pm 0.33^{\mathrm{b}}$ & $39.97 \pm 0.55^{\mathrm{b}}$ & $20.33 \pm 1.29^{\mathrm{a}}$ & $6.25 \pm 0.36^{\mathrm{b}}$ & $22.75 \pm 0.90^{\mathrm{h}}$ & $330.15 \pm 2.89^{\mathrm{i}}$ & $81.27 \pm 0.22^{b}$ \\
\hline
\end{tabular}

Values reported are means \pm standard deviation of triplicate determinations. Mean values bearing different superscript roman letters are significantly $(\mathrm{P}<0.05)$ different from one another. Ra: Raw; B: Boiled; R: Roasted; A: Autoclaved ; G: Germinated; F: Fermented; GF: Germinated fermented; DB: Defatted boiled; DR: Defatted roasted; DA: Defatted autoclaved ; DG: Defatted germinated; DF: Defatted fermented; DGF: Defatted germinated fermented 
The low energy value observed in boiled, germinated and all defatted flour samples could be attributed to the decrease in fat content of the flour samples.

\section{In vitro protein digestibility of full fat and defatted processed kariya seed flour}

The results of in vitro protein digestibility of full fat and defatted flour of processed kariya seed are shown in Table 1 . The in vitro protein digestibility of the samples ranged from $27.86-82.63 \%$ with the raw sample having the lowest value $(27.86 \%)$ and the defatted fermented sample having the highest value (82.63\%). In vitro protein digestibility significantly increased in all the samples. This agrees with the observation of Adu et al. [32] that heat processing improves protein digestibility significantly. This might be attributed to the effect of heat on the protease inhibitor and denaturation of protein especially globulin which commands the open up of their structure and increase the chain flexibility and hence less resistance against digestive proteases [26]. The increase in protein digestibility could as well be attributed to the degradation or reduction of antinutrients such as tannins and phytic acid by microbial enzymes, fermentation, germination and heat treatments [33,34].

\section{Physicochemical and functional properties of full fat and defatted flour of processed kariya seed flour}

The results of physicochemical properties (bulk density and $\mathrm{pH}$ ) and functional properties of full fat and defatted kariya seed flour samples are presented in Table 2 .

\section{Bulk density}

The bulk density of the samples ranged between 0.52-0.75 (g/ $\mathrm{ml})$. The range of values reported in this study compared favourably with the result $(0.57 \mathrm{~g} / \mathrm{ml})$ reported by Adebayo et al. [5] for defatted kariya flour and processed pinto bean $(0.42-0.69 \mathrm{~g} / \mathrm{ml})$ reported by Audu et al. [35] but lower than the value $(1.00-1.04 \mathrm{~g} / \mathrm{ml})$ reported by Akpossan et al. [36] for Imbrasia oyemensis full fat flour and defatted flour. There was significant decrease $(\mathrm{p}<0.05)$ in the bulk density of germinated sample which could be as a result of the breakdown of high molecular weight macromolecules to low molecular weight molecules by enzymes. This is similar to the observation of Chinma et al. [37] on germinated moringa seed flour. Fermentation and a combination of germination and fermentation increased bulk density significantly and this was in agreement with the observation of Omowaye-Taiwo et al. [38] on melon seeds but in contrast to the report given by Oloyede et al. [39] that bulk density decreases with fermentation time.

Bulk density is the measured by weight per volume and expressed as $\mathrm{g} / \mathrm{ml}$. Bulk density value is of importance in food packaging, transportation and diet formulations.

\section{pH}

There were reduction in the $\mathrm{pH}$ values of all the samples and significant increase in $\mathrm{pH}$ was observed in defatted flour samples. The processing conditions generally increased the acidity of the samples. Fermentation and germination processes brought about significant increase in the acidity. This might be due to the production of some organic acids during fermentation. $\mathrm{pH}$ is of great importance in flour suspension as functional properties of the flour largely depends on $\mathrm{pH}$ [40].

\section{Oil absorption capacity (OAC) of processed kariya seed flour}

The OAC of the samples ranged from $65.50-144.60 \%$. The trend was similar to the OAC values (63-83\%) reported by Adegunwa et al. [41] for benni seed. The OAC of roasted, autoclaved, fermented and germinated-fermented kariya samples were observed to be lower than the OAC of raw sample. There was increase in the OAC of boiled and germinated samples. The boiled full fat flour sample had the highest OAC (109\%) among the full fat flour samples and the increase in fat absorption is associated with heat dissociation of the proteins and denaturation which is expected to unmask the nonpolar residue from the interior of protein molecules [42]. Similar observation was reported by Fawale et al. [25] for cooked unfermented kariya. Germination increased oil absorption capacity and similar observation was reported by Wisaniyasa [43] for fluted pumpkin seed.

There was significant increase $(\mathrm{p}<0.05)$ in the OAC of the defatted samples compared to the full fat samples and this agrees with the value reported by Ogunsina et al. [31] for full fat and defatted moringa seed flour. This shows that defatting increased oil absorption capacity and defatted flour can find good applications in food formulation where high OAC is required such as in meat, pastries and bakery products production.

Table 2. Physicochemical and functional properties of raw and processed Kariya flour

\begin{tabular}{|c|c|c|c|c|c|c|}
\hline $\begin{array}{l}\text { Sample } \\
\text { Code }\end{array}$ & Bulk Density (g/ml) & pH & $\begin{array}{l}\text { Water Absorption } \\
\text { Capacity }(\%)\end{array}$ & $\begin{array}{c}\text { Oil Absorption } \\
\text { Capacity (\%) }\end{array}$ & $\begin{array}{l}\text { Emulsifying Activity Index } \\
\qquad\left(\mathrm{g} / \mathbf{m}^{2}\right)\end{array}$ & $\begin{array}{c}\text { Emulsifying } \\
\text { Stability } \\
\text { Index (\%) }\end{array}$ \\
\hline $\mathbf{R a}$ & $0.63 \pm 0.00^{\mathrm{d}}$ & $6.84 \pm 0.05^{\mathrm{a}}$ & $46.40 \pm 1.60^{\mathrm{g}}$ & $91.30 \pm 2.50^{\mathrm{e}}$ & $11.66 \pm 0.09^{j}$ & $105.62 \pm 0.40^{\mathrm{j}}$ \\
\hline B & $0.55 \pm 0.01^{\mathrm{g}}$ & $6.34 \pm 0.01^{\mathrm{c}}$ & $143.50 \pm 7.5^{\mathrm{c}}$ & $109.00 \pm 4.00^{c}$ & $21.48 \pm 0.11^{\mathrm{d}}$ & $113.78 \pm 0.80^{\mathrm{g}}$ \\
\hline $\mathbf{R}$ & $0.60 \pm 0.02^{\mathrm{e}}$ & $6.03 \pm 0.02^{\mathrm{f}}$ & $80.20 \pm 6.40^{\mathrm{f}}$ & $89.90 \pm 2.90^{\mathrm{e}}$ & $21.33 \pm 0.03^{\mathrm{d}}$ & $108.74 \pm 0.50^{\mathrm{i}}$ \\
\hline $\mathbf{A}$ & $0.74 \pm 0.00^{\mathrm{ab}}$ & $6.24 \pm 0.02^{\mathrm{d}}$ & $53.00 \pm 4.80^{\mathrm{g}}$ & $65.50 \pm 3.30^{\mathrm{g}}$ & $21.53 \pm 0.16^{\mathrm{d}}$ & $121.10 \pm 0.25^{\mathrm{e}}$ \\
\hline G & $0.56 \pm 0.00^{\mathrm{f}}$ & $6.10 \pm 0.08^{\mathrm{e}}$ & $92.60 \pm 7.80^{\mathrm{e}}$ & $99.10 \pm 3.90^{\mathrm{d}}$ & $21.90 \pm 0.70^{\mathrm{c}}$ & $128.26 \pm 0.18^{c}$ \\
\hline $\mathbf{F}$ & $0.73 \pm 0.01^{\mathrm{b}}$ & $5.64 \pm 0.03^{\mathrm{f}}$ & $130.80 \pm 8.20^{\mathrm{d}}$ & $80.70 \pm 3.70^{\mathrm{f}}$ & $25.42 \pm 0.18^{\mathrm{a}}$ & $134.62 \pm 0.43^{\mathrm{a}}$ \\
\hline GF & $0.75 \pm 05.00^{\mathrm{a}}$ & $5.33 \pm 0.03^{\mathrm{k}}$ & $143.70 \pm 6.90^{\mathrm{c}}$ & $86.10 \pm 3.50^{\text {ef }}$ & $22.32 \pm 0.22^{\mathrm{b}}$ & $130.76 \pm 0.67^{b}$ \\
\hline DB & $0.52 \pm 0.01^{\mathrm{g}}$ & $6.37 \pm 0.02^{b}$ & $218.50 \pm 9.50^{\mathrm{a}}$ & $144.60 \pm 0.40^{\mathrm{a}}$ & $16.45 \pm 0.06^{\mathrm{i}}$ & $104.70 \pm 0.88^{\mathrm{j}}$ \\
\hline DR & $0.58 \pm 0.01^{\mathrm{ef}}$ & $6.09 \pm 0.02^{\mathrm{e}}$ & $96.10 \pm 2.50^{\mathrm{e}}$ & $103.00 \pm 4.40^{\mathrm{cd}}$ & $16.26 \pm 0.13^{\mathrm{i}}$ & $102.10 \pm 1.17^{\mathrm{k}}$ \\
\hline DA & $0.57 \pm 0.01^{\mathrm{ef}}$ & $6.27 \pm 0.02^{\mathrm{d}}$ & $75.90 \pm 6.90^{\mathrm{f}}$ & $117.20 \pm 6.20^{\mathrm{b}}$ & $18.34 \pm 0.69^{\mathrm{g}}$ & $108.76 \pm 0.29^{i}$ \\
\hline DG & $0.52 \pm 0.00^{\mathrm{g}}$ & $6.23 \pm 0.02^{\mathrm{d}}$ & $102.20 \pm 4.60^{\mathrm{e}}$ & $119.60 \pm 7.40^{\mathrm{b}}$ & $17.70 \pm 0.09^{\mathrm{h}}$ & $112.61 \pm 0.48^{\mathrm{h}}$ \\
\hline DF & $0.65 \pm 0.01^{\mathrm{c}}$ & $5.72 \pm 0.01^{\mathrm{h}}$ & $179.10 \pm 7.30^{\mathrm{b}}$ & $117.80 \pm 6.40^{\mathrm{b}}$ & $20.63 \pm 0.18^{\mathrm{e}}$ & $123.97 \pm 0.29^{\mathrm{d}}$ \\
\hline DGF & $0.63 \pm 0.01^{\mathrm{d}}$ & $5.50 \pm 0.03^{j}$ & $175.90 \pm 6.90^{\mathrm{b}}$ & $108.00 \pm 0.80^{c}$ & $18.79 \pm 0.60^{\mathrm{f}}$ & $118.43 \pm 0.32^{\mathrm{f}}$ \\
\hline
\end{tabular}

Values reported are means \pm standard deviation of triplicate determinations. Mean values bearing different superscript roman letters are significantly (P<0.05) different from one another. Ra: Raw; B: Boiled; R: Roasted; A: Autoclaved; G: Germinated; F: Fermented; GF: Germinated fermented; DC: Defatted boiled; DR: Defatted roasted; DA: Defatted autoclaved; DG: Defatted germinated; DF: Defatted fermented; DGF: Defatted germinated fermented 


\section{Water absorption capacity (WAC) of raw and processed kariya seed flours}

All the processing methods influenced WAC and there was significant difference $(\mathrm{p}<0.05)$ in WAC of all the samples. Among all the processing conditions, autoclaved samples had the lowest $(53 \%)$ while germinated-fermented samples had the highest WAC (143.70\%). Water absorption capacity of all the processed flours significantly increased compared to the raw sample. According to Oloyede et al. [39] the low water absorption capacity recorded for raw sample is an indication of intact starch granules in the raw flour.

Hotz and Gibson [8] reported that heat treatment can change hydration properties and cause variations in the WAC of the autoclaved, steam-cooked and roasted samples because the kinetics of water uptake however were different. Also, there was significant increase in WAC of germinated-fermented (143.70\%) and fermented samples $(130.80 \%)$ compared to germinated sample (92.60\%) and this could be attributed to the modification of macromolecules during fermentation.

Defatted flour samples exhibited higher WAC than the full fat flour samples. The WAC of defatted treated samples ranged from $75.90-218.50 \%$. The reduction in fat content resulted in increase in protein and carbohydrate and subsequent increase in WAC. According to Sila and Malleshi [44] flours with high WAC has more hydrophilic constituent as polysaccharides. Product of high WAC can serve as good thickening agent and be used as a thickener or gelling agent in various food products.

\section{Emulsifying activity index (EAI) and emulsifying stability (ES) of raw and processed kariya seed flour}

At natural $\mathrm{pH}$ of the samples, the EAI ranged from 11.66-25.42 $\mathrm{m}^{2} / \mathrm{g}$ with significant differences $(\mathrm{p}<0.05)$ between the highest and lowest EAI values. Among the treated samples, fermented sample had the highest EAI value $\left(25.42 \mathrm{~m}^{2} / \mathrm{g}\right)$ and similar observation was reported by Fawale et al. [25]. The high EAI value observed in fermented sample could be attributed to its high fat content and the hydrolysis of higher molecular protein peptide to lower molecular protein peptide with high lipophilic ends [45].

The emulsion stability of samples ranged from $102.10-134.62 \%$ with fermented sample having the highest value (134.62\%) and defatted roasted sample had the lowest value (102.10\%). Emulsion stability shows the ability of protein to impact strength to an emulsion for resistance to stress and changes or to reduce the interfacial tension between oil and water in the emulsion [46] However, decrease in surface tension of the oil droplet by providing electrostatic repulsion on the surface of the oil droplet prevents coalescence and this brings about emulsion stability [47].

Fermentation significantly increased EAI and ES and this agrees with the report of Oloyede et al. [39] for Moringa olifera seed. With this property it gives an indication that the flour can be used in certain food systems e.g frozen desserts, whippings, toppings, mayonnaise, yoghurt and salad dressing.

Emulsion capacity is the maximum quantity of oil that can be emulsified by protein dispersion whereas emulsion stability indicates the ability of an emulsion with a known composition to remain unchanged [48].

\section{Influence of temperature on water absorption capacity (WAC) of raw and processed kariya seed flour}

The WAC of raw and processed kariya flour as influenced by temperature changes is presented in Figure 1. The WAC of all the samples increased as temperature increases. Gradual increase in WAC was observed in boiled, fermented and germinated-fermented processed full fat kariya flour samples and the defatted flour samples as the temperature increases. A spontaneous increase was observed in the autoclaved, roasted and germinated full fat flour samples. The difference in protein structure and the presence of different hydrophilic carbohydrates as a result of variation in processing treatment might be responsible for variation in the WAC of the flour samples. The water absorption capacity of defatted kariya seed flour is shown in Figure 2. Similar observation was reported for the full fat flour samples but the defatted flour samples had higher water absorption capacities. The removal of fat from samples exposed the water binding sites on the side chain groups of protein units previously blocked in a lipophilic environment thereby leading to an increase in WAC values in defatted flour [49].

According to Lagnika et al. [50], water absorption capacity is the ability of flour to absorb water and swell for improved consistency in food.



Figure 1. Influence of temperature on water absorption capacity of raw kariya flour and whole flour of kariya subjected to different processing treatments 


\section{Influence of temperatures on swelling capacity of raw and processed kariya seed flour}

The results of the influence of temperature changes on swelling capacity of full fat and defatted kariya flour samples are shown in Figures 3 and 4 respectively. Swelling capacity increased as the temperature increases and the highest swelling capacity was observed at the highest temperature $\left(90^{\circ} \mathrm{C}\right)$ which ranged from $134.00-264.00^{\circ} \mathrm{C}$ for full fat samples and $203.00-309.67^{\circ} \mathrm{C}$ for defatted flour samples. The lowest swelling capacity was observed at the lowest temperature $\left(60^{\circ} \mathrm{C}\right)$. The swelling capacity at $60^{\circ} \mathrm{C}$ ranged from $69-203^{\circ} \mathrm{C}$ for full fat flour and $104-288^{\circ} \mathrm{C}$ for defatted flour samples. This agrees with the result reported by James et al. [51] that temperature increase caused vigorous starch vibration which breaks intermolecular bonds and thereby allowing hydrogen bonding sites to accommodate more water molecules. Also, Bhat and Riar [52] reported that swelling power of starches increased with increase in temperature and this could be attributed to reduction in gelatinization temperature.

\section{Antinutrients of raw and processed kariya seed flour}

The antinutrients of processed kariya flour samples are presented in Table 3. It was observed that the various processes resulted in the reduction of the selected antinutrients. The level of reduction ranged



Figure 2. Influence of temperature on water absorption capacity of defatted flour of kariya subjected to different processing treatments



Figure 3. Influence of temperature on swelling capacity of raw kariya and whole flour of kariya subjected to different processing treatments



Figure 4. Influence of temperature on swelling capacity of defatted flour of kariya subjected to different processing treatments 
Table 3. Anti-nutrients value of raw and processed Kariya seed flour $(\mathrm{mg} / 100 \mathrm{~g})$

\begin{tabular}{|c|c|c|c|c|}
\hline Sample & Tanin & Saponin & Oxalate & Phytate \\
\hline $\mathbf{R a}$ & $1.58 \pm 0.13^{\mathrm{bc}}$ & $2.37 \pm 0.17^{\mathrm{a}}$ & $4.29 \pm 0.55^{\mathrm{a}}$ & $14.72 \pm 0.64^{\mathrm{a}}$ \\
\hline B & $0.53 \pm 0.13^{\mathrm{e}}$ & $1.89 \pm 0.06^{\mathrm{b}}$ & $1.42 \pm 0.09^{f}$ & $7.68 \pm 0.64^{e}$ \\
\hline $\mathbf{R}$ & $1.06 \pm 0.13^{\mathrm{d}}$ & $1.51 \pm 0.01^{\mathrm{cd}}$ & $1.98 \pm 0.22^{\mathrm{ef}}$ & $7.04 \pm 0.64^{f}$ \\
\hline $\mathbf{A}$ & $0.59 \pm 0.06^{\text {ef }}$ & $1.46 \pm 0.01^{\mathrm{de}}$ & $1.59 \pm 0.15^{\mathrm{ef}}$ & $8.32 \pm 0.64^{e}$ \\
\hline G & $0.86 \pm 0.07^{\mathrm{de}}$ & $1.57 \pm 0.20^{\mathrm{c}}$ & $2.86 \pm 0.00^{\mathrm{bc}}$ & $5.12 \pm 0.64^{\mathrm{g}}$ \\
\hline $\mathbf{F}$ & $1.85 \pm 0.26^{\mathrm{b}}$ & $1.33 \pm 0.03^{\mathrm{fg}}$ & $0.88 \pm 0.00^{\mathrm{g}}$ & $5.76 \pm 0.64^{\mathrm{g}}$ \\
\hline GF & $3.57 \pm 0.26^{\mathrm{a}}$ & $1.38 \pm 0.03^{\mathrm{ef}}$ & $2.42 \pm 0.22^{\text {cde }}$ & $5.13 \pm 0.11^{\mathrm{g}}$ \\
\hline DB & $0.33 \pm 0.06^{\mathrm{f}}$ & $1.43 \pm 0.02^{\text {def }}$ & $2.86 \pm 0.44^{\mathrm{bc}}$ & $10.56 \pm 0.32^{\mathrm{d}}$ \\
\hline DR & $0.46 \pm 0.06^{\mathrm{f}}$ & $1.24 \pm 0.03^{\mathrm{ghi}}$ & $2.64 \pm 0.22^{\mathrm{bcd}}$ & $11.53 \pm 0.64^{\mathrm{c}}$ \\
\hline DA & $0.40 \pm 0.13^{\mathrm{f}}$ & $1.23 \pm 0.03^{\mathrm{hi}}$ & $2.36 \pm 0.06^{\mathrm{de}}$ & $13.76 \pm 0.32^{\mathrm{b}}$ \\
\hline DG & $0.33 \pm 0.07^{\mathrm{f}}$ & $1.27 \pm 0.02^{\mathrm{gh}}$ & $4.18 \pm 0.22^{\mathrm{a}}$ & $7.68 \pm 0.64^{\mathrm{ef}}$ \\
\hline DF & $1.39 \pm 0.20^{\mathrm{c}}$ & $1.01 \pm 0.01^{\mathrm{j}}$ & $2.31 \pm 0.11^{\mathrm{de}}$ & $8.00 \pm 0.32^{\text {ef }}$ \\
\hline DGF & $1.58 \pm 0.26^{\mathrm{bc}}$ & $1.23 \pm 0.03^{\mathrm{hi}}$ & $2.97 \pm 0.33^{b}$ & $7.36 \pm 0.32^{\text {ef }}$ \\
\hline
\end{tabular}

Values reported are means \pm standard deviation of triplicate determinations. Mean values bearing different superscript roman letters are significantly (P<0.05) different from one another. Ra: Raw; B: Boiled; R: Roasted; A: Autoclaved; G: Germinated; F: Fermented; GF: Germinated fermented; DB: Defatted boiled; DR: Defatted roasted; DA: Defatted autoclaved; DG: Defatted germinated; DF: Defatted fermented; DGF: Defatted germinated fermented

between 0.0 and $79.11 \%$ (tannin); 20.25 to $57.38 \%$ reduction in the level of saponin; 2.56 to $78.49 \%$ reduction in the level of oxalate and 6.52 to $65.21 \%$ reduction in the level of phytate.

It was observed that tannin in the processed flour samples reduced in all the samples compared with the raw sample. The germinated samples recorded significant reduction in the level of tannin, however, it was observed that fermented, germinated/fermented samples did not follow the pattern. This was in contrast to the observation of Raihanatu et al. [53] for the sprouted and fermented five varieties of sorghum but it agrees with the observations reported by Osman [33] and Sathya and Siddhuraju [26] for traditionally fermented pearl millet for "loloh" preparation and Pakia roxburghii (locust bean) respectively. The increase in the tannin content of the fermented kariya sample could be attributed to hydrolysis of condensed tannins such as proanthocyanidin. The increase in tannin content may adversely affect the nutritional quality of fermented kariya flour. According to Sarwar et al. [54], high tannin concentration in diet may cause depressed microbial enzyme activities during intestinal digestion however in spite of the known adverse action on protein digestibility, seed tannins might exert a beneficial antioxidant activity and contribute to diseases prevention.

The heating and biochemical processes into which the kariya seeds were subjected reduced the level of the saponin present in the flour samples. The process of defatting also enhanced the reduction of the antinutrient. This observation agrees with the report of Kaur et al. [55] that extracting solvent has potential to reduce the inherent antinutrients due to solubility of the components.

Heating processes promoted reduction in the level of oxalate present in the processed kariya flour samples. Furthermore, it was observed that fermentation process caused a noticeable reduction in oxalate content better than combination of germination and fermentation processes. Defatted flour samples had lower oxalate content compared to full fat kariya flour samples.

Phytate content of defatted flour samples were lower than those of full fat samples. Heating processes reduced the level of phytate in the heat processed samples but not as much as in the biochemically processed samples. The germinated and germinated/fermented samples were of lower phytate content. Phytates according to Gupta et al.[56] are referred to as heat stable antinutrient- Similar observation was reported by Kaur et al. [55] who recorded $88.30 \%$ reduction in phytate content when germinated pearl millet sprouts were fermented with selective culture media. According to Gupta et al. [56], natural fermentation caused large reduction in phytic acid in rice flour by the action of microbes as well as grain phytase. This reduction could be attributed to the activity of the endogenous phytase enzyme from the raw ingredient and inherent microorganisms which are capable of hydrolysing the phytic acid in the fermented food preparations into inositol and orthophosphate [57].

\section{Conclusion}

The study concluded that processing treatments improved the physicochemical and functional characteristics of the biomaterial (kariya). Defatting concentrated the nutrients. Moreover, fermentation, germination and combination of fermentation and germination treatments caused significant improvement in some of the nutrients. All the processing treatments significantly reduced the antinutrient levels except for tannin content of fermented and germinated-fermented kariya flour which increased.

\section{References}

1. IITA (2012) Hildegardia barteri okurugbedu (Yoruba). International Institute of Tropical Agriculture. Available on http://www.reforest-iita.org/home/84-hildegardiabarteri-okurugbedu-yoruba.html.

2. Inglett GE, Cavins JF, Spencer GF (1973) Seed compositions of Hildergardia barteri. Economic Botany Journal 27: 128-130.

3. Ogunsina BS, Olaoye IO, Adegbenjo AO, Babawale BD (2011) Nutritional and

4. Physical properties of Kariya seeds (Hidergardia bateri). International Agrophysics 25: $97-100$.

5. Ikujenlola AV, Ahmida AF, Gbadamosi OS (2017) Nutritional quality and safety assessment of complementary food produced from Acha (Digitaria exilis) flour and Kariya (Hildergardia barteri) protein concentrate blends. J Food Chem Nanotechnol 3: 24-30.

6. Adebayo WA, Ogunsina BS, Gbadamosi SO (2013) Some physico-chemical and functional properties of kariya (Hildegardia baterii) kernel flours. Ife Journal of Science 15: 477-486.

7. Adiamo OQ, Gbadamosi SO, Abiose SH (2015) Functional properties and protein digestibility of protein concentrates and isolates produced from kariya seed. Journal of Food Processing and Preservation 40: 979-989.

8. Famuwagun AA, Gbadamosi SO (2016) Evaluation of proximate, functional and antioxidative properties of enzymatic hydrolysates from fermented kariya (Hildergardia barterii) seed protein isolates. Annals of Food Science and Technology 7: 22-33.

9. Hotz C, Gibson RS (2007) Traditional food processing and processing and preparation practices to enhance the bioavailability of micronutrients in plants-based diet. The Journal of Nutrition 137: 1097-1100. 
10. AOAC (2000) Official Methods of Analysis of AOAC International, $17^{\text {th }}$ ed. Association of Official Analytical Chemists, Washington, DC.

11. Alobo AP, Agbo BN, Ilesanmi SA (2009) Physicochemical and functional properties of full fat and defatted cashew kernel flours. International Journal of Food Science and Technology 44: 581-585.

12. Chavan UD, Mckenzie DB, Shahidi F (2001) Functional properties of protein isolates from beach pea (Lathyrus maritimus L.). Journal of Food Chemistry 74: 177-187.

13. Price ML, Van SS, Butter LG. (1978) A critical evaluation of the vanillin reaction as an assay for tannin in sorghum grain. Journal of Agriculture and Food Chemistry 26: 1214-1218.

14. Falade OS, Dare AF, Bello MO, Osuntogun BO, Adewusi SRA (2004) Varietal changes in proximate composition and the effect of processing on the ascorbic acid content of some Nigerian vegetable. Journal of Food Technology 2: 103-108.

15. Brunner JH (1984) Direct spectrophotometric determination of saponin. Journal of Analytical Chemistry 34: 1314-1326.

16. Reddy NR, Balakrishnan CV, Salunkhe DK (1978) Phytate phosphorus and mineral changes during germination and cooking of blackgram (Phaseous mungo) seeds. Journal of Food Science 43: 540-543.

17. Okezie BO, Bello AB (1988) Physicochemical and functional properties of winged bean flour and isolate compared with soy isolate. Journal of Food Science 53: 450-454

18. AACC (1995) Approved methods of AACC (9th ed, Vols. 1 and 2) St. Paul, MN: American Association of Cereal Chemists.

19. Beuchat LR (1977) Functional and electrophoretic characteristics of succinylated peanut flour protein. Journal of Agricultural Food Chemistry 25: 258-261.

20. Takashi S, Seib PA (1988) Paste and gel properties of prime corn and wheat starches with and without native lipids. Journal of Cereal Chemistry 65: 474-480.

21. Gbadamosi SO, Abiose SH, Aluko RE (2012) Amino acid profile, protein digestibility, thermal and functional properties of conophor nut (Tetracarpidium conophorum) defatted flour, protein concentrate and isolates. International Journal of Food Science and Technology 47: 731-739.

22. Erkmen O, Bozoglu TF (2016) Food Microbiology: Principles and Practice. Food preservation by reducing water activity. John Willey and sons.

23. Li YC, Qian H, Sun X, Cui Y, Wang H, et al. (2014) The Effects of germination on chemical composition of peanut seed. Japanese Society for Food Science and Technology 20: 883-889.

24. Nkhata SG, Ayua E, Kamau EH, Shingiro JB (2018) Fermentation and germination improve nutritional value of cereals and legumes through activation of endogenous enzymes. Food Sci Nutri.

25. Ocheme OB, Adedeji OE, Chinma CE, Yakubu CM, Ajibo UH (2018) Proximate composition, functional, and pasting properties of wheat and groundnut protein concentrate flour blends. Food Sci Nutr 6: 1173-1178.

26. Fawale OS, Gbadamosi SO, Ige MM, Kadiri O (2017) Effects of cooking and fermentation on the chemical composition, functional, and antinutritional properties of kariya (Hildergardia barteri) seeds. Food Sci Nutr.

27. Sathya A, Siddhuraju R (2015) Effect of processing methods on compositional evaluation of underutilized legume, Pakia roxburghii (yongohak) seeds. Journal of Food Science and Technology 52: 6157-6169.

28. Natalie ED, Benjamin PW (2019) Microbial fermentation of dietary protein: An important factor in diet-microbe-host interaction. Microorganisms 7.

29. Ali AS, Elozeiri AA (2017) Metabolic processes during seed germination. Advances in Seed Biology.

30. Kang SW, Rahman MS, Kim AN, Lee KY, Park CY, et al. (2017) Comparative study of the quality characteristics of defatted soyflour treated by supercritical carbon dioxide and organic solvent. J Food Sci Technol 54: 2485-2493.

31. Udoh IE (2017) Nutritional and chemical properties of fluted Pumpkin (Telfairia occidentalis) seed flours, protein concentrates and isolates. Nigerian Journal of Agriculture, Food and Environment 13: 206-213.

32. Ogunsina BS, Adegbenjo AO, Opeyemi OO (2010) Compositional, mass-volumearea related and mechanical properties of sponge gourd (Luffa aegyptiaca) seeds. International Journal of Food Properties 13: 864-876.

33. Adu OB, Ogundeko TO, Ogunrinola OO, Saibu GM, Elemo BO (2017) The effect of thermal processing on protein quality and freeamino acid profile of Terminalia catappa (Indian Almond) seed. J Food Sci Technol 52: 4637-4641.
34. Osman MA (2011) Effect of traditional fermentation process on the nutrient and antinutrient contents of pearl millet during preparation of lohoh. Journal of the Saudi Society of Agricultural Sciences 10: 1-6.

35. Ogodo AC, Agwaranze DI, Aliba NV, Kalu AC, Nwaneri CB (2019) Fermentation by lactic acid bacteria consortium and its effect on anti-nutritional factors in maize flour. Journal of Biological Sciences 19: 17-23.

36. Audu SS, Aremu MO, Lajide L, Oko OJ (2014) Functional properties of processed pinto bean (Phaseolus vulgaris L.) grown in Plateau State, Nigeria. Journal of Chemical and Process Engineering Research 24.

37. Akpossan RA, Digbeu YD, Koffi MD, Kouadio JPEN, Dué EA, et al. (2015) Protein fractions and functional properties of dried Imbrasia oyemensis larvae full-fat and defatted flours. International Journal of Biochemistry Research \& Revie 5: 116-126.

38. Chinma CE, Lata LJ, Chukwu TM, Azeez SO, Ogunsina BS, et al. (2017) Effect of germination time on the proximate composition and functional properties of moringa seed flour. African Journal of Agriculture, Technology and Environment 6: 117-133.

39. Omowaye-Taiwo OA, Fagbemi TN, Ogunbusola EM, Badejo AA (2015) Effect of germination and fermentation on the proximate composition and functional properties of full-fat and defatted Cucumeropsis mannii seed flours. Journal of Food Science and Technology 52: 5257-5263.

40. Oloyede OO, Samaila J, Ocheme O B, Chinma EC, Akpa VE (2016) Effects of fermentation time on the functional and Pasting properties of defatted Moringa oleifera seed flour. Journal of Food Science and Nutrition 4: 89-95.

41. Adepeju AB, Gbadamosi SO, Adeniran AH, Omobuwajo TO (2011) Functional and pasting characteristics of breadfruit (Artocarpus altilis) flours. African Journal of Food Science 5: 529-535.

42. Adegunwa MO, Adebowale AA, Solano EO (2012) Effect of thermal processing on the biochemical composition, antinutritional factors and functional properties of beniseed (Sesamum indicum) flour. American Journal of Biochemistry and Molecular Biology 2: $175-182$.

43. Ojinnaka MC, Emeh TC, Okorie SU (2016) Evaluation of the quality of composite maize-wheat chinchin enriched with Rhynchophorous phoenicis. Journal of Food Research.

44. Wisaniyasa NW, Suter IK, Marsono Y, Putra IK (2015) Germination effect on functional properties and antitrypsin activities of pigeon pea (Cajanus cajan (L.) Millsp.) sprout flour. Food Science and Quality Management.

45. Sila B, Malleshi NG (2012) Physical, chemical and nutritional characteristics of premature-processed and matured green legumes. Journal of Food Science and Technology 49: 459-466.

46. Yuan H, Wang H, Wang L, Chai L, Tian C (2017) Nutritional evaluation and Functional properties of the antioxidant polypeptide from Zanthoxylum bungeanum Maxim seeds kernel protein hydrolysate, CyTA. Journal of Food 15: 425-432.

47. Singh B, Kunze G, Satyanaraya T (2011) Development in biochemical aspect and biotechnological applications of microbial phytase. Journal of Biotechnological and Molecular Biology Revolution 6: 69-87.

48. Maphosa Y, Jideani VA (2018) Factors affecting the stability of emulsions stabilized by biopolymers. Intechopen.

49. Molet-Rodríguez A, Salvia-Trujillo L, Martín-Belloso O (2018) Beverage emulsions: Key aspects of their formulation and physicochemical stability. Beverages 4.

50. Akinola SA, Enujiugha VN (2017) Physicochemical and sensory qualities of "Aadun" a maize based snack supplemented with defatted african oil bean seed flour. Applied Tropical Agriculture 22: 188-196.

51. Lagnika C, Houssou PAF, Dansou V, Hotegni AB, Amoussa AMO, et al. (2019) Physico-functional and sensory properties of flour and bread made from composite wheat-cassava. Pakistan Journal of Nutrition 18: 538-547.

52. James S, Akosu NI, Maina YC, Baba AI, Nwokocha L, et al. (2018) Effect of addition of processed bambara nut on the functional and sensory acceptability of millet-based infant formula. Food Sci Nutr 6: 783-790.

53. Bhat FM, Riar CS (2017) Studies on effect of temperature and time on textural and rheological properties of starch isolated from traditional rice cultivars of Kashmir (India). Journal of Texture Studies 48: 151-159.

54. Raihanatu SM, Modu S, Falmata AS, Shettima YA, Heman M (2011) Effect of processing (sprouting and fermentation) of five local varieties of sorghum and some biochemical parameters. Journal of Biokemistri 23: 91-96. 
Gbadamosi SO (2020) Heating and Biochemical processing of Kariya (Hildegardia bateri) seeds: Chemical composition, antinutrients and functional properties

55. Sarwar GG, Wu XC, Cockell K (2012) Impact of antinutritional factors in food proteins on the digestibility of protein and the bioavailability of amino acids and on protein quality. British Journal of Nutrition 108: S315-S332.

56. Kaur M, Kaushal P, Sandhu KS (2013) Studies on physicochemical and pasting properties of taro (Colocasia esculenta $L$.) flour in comparison with a cereal, tuber and legume flour. Journal of Food Science and Technology 50: 94-100.
57. Gupta RK, Gangoliya SS, Singh NK (2015) Reduction of phytic acid and enhancement of bioavailable micronutrients in food grains. Journal of Food Science and Technology 52: 676-684.

58. Suleiman B (2019) Effects of fermentation on the nutritional status of Crescentia seed and its potentiality as aqua feedstuff. Animal Research International 16: 3207-3212.

Copyright: (C2020 Gbadamosi SO. This is an open-access article distributed under the terms of the Creative Commons Attribution License, which permits unrestricted use, distribution, and reproduction in any medium, provided the original author and source are credited. 